\title{
HUBUNGAN ANTARA LITERASI DIGITAL DENGAN PRESTASI BELAJAR SISWA SMA NEGERI 6 KOTA BOGOR
}

\author{
Farleynia Giovanni \\ Universitas Padjadjaran \\ farleyniagiovanni26@gmail.com \\ Neneng Komariah \\ Universitas Padjadjaran \\ neneng.komariah@unpad.ac.id
}

\begin{abstract}
Digital literacy is the ability to understand and use information in various forms from a variety of very broad sources that are accessed through computer devices. Learning achievement is the result of learning activities, namely the extent to which students master the material of the lesson being taught, followed by the emergence of feelings of satisfaction that he has done something well. The purpose of this study was to determine the relationship between digital literacy and student achievement in SMA Negeri 6 Bogor. Digital literacy consists of information competencies, communication competencies, content creation competencies, and security competencies. While learning achievement is measured by ranking. This study uses a quantitative approach with a correlation method. The population in this study were students of SMA Negeri 6 Bogor in class X and XI in 2018/2019 with sample criteria using probability sampling techniques. Data collection techniques in this study used questionnaires, observations, and literature. The analysis technique used is descriptive data analysis techniques and inferential analysis.
\end{abstract}


The results and conclusion of this study indicate that there is a significant relationship between information competency, communication competency, content creation competency, and security competence with student learning achievement.

Keywords: Digital Literacy, Literacy Competence, Learning Achievement, Ranking

\begin{abstract}
Abstrak
Literasi digital adalah kemampuan untuk memahami dan menggunakan informasi dalam berbagai bentuk dari berbagai sumber yang sangat luas yang diakses melalui piranti komputer. Prestasi belajar merupakan hasil kegiatan belajar, yaitu sejauh mana peserta didik menguasai bahan pelajaran yang diajarkan, yang diikuti oleh munculnya perasaan puas bahwa ia telah melakukan sesuatu dengan baik. Tujuan penelitian ini adalah untuk mengetahui hubungan antara literasi digital dengan prestasi belajar siswa SMA Negeri 6 kota Bogor. Literasi digital terdiri dari kompetensi informasi, kompetensi komunikasi, kompetensi kreasi konten, dan kompetensi kemanan. Sedangkan prestasi belajar diukur dari rangking. Penelitian ini menggunakan metode pendekatan kuantitatif dengan metode korelasi. Populasi pada penelitian ini adalah siswa SMA Negeri 6 kota Bogor kelas X dan XI tahun 2018/2019 dengan kriteria sampel menggunakan teknik probability sampling. Teknik pengumpulan data dalam penelitian ini menggunakan kuisioner, observasi, dan studi pustaka. Teknik analisis yang digunakan adalah teknik analisis data deskriptif dan analisis inferensial. Hasil dan simpulan dari penelitian ini menunjukan adanya hubungan yang signifikan antara kompetensi informasi, kompetensi komunikasi, kompetensi kreasi konten, dan kompetensi keamanan dengan prestasi belajar siswa.
\end{abstract}

Kata Kunci: Literasi Digital, Kompetensi Literasi, Prestasi Belajar, Rangking 


\section{A. Pendahuluan}

Literasi sudah menjadi bagian dari kehidupan dan perkembangan manusia, dari zaman prasejarah hingga zaman modern. Kemajuan infrastruktur transportasi dan telekomunikasi, termasuk kemunculan telegraf dan internet, merupakan faktor utama dalam globalisasi yang semakin mendorong saling ketergantungan (interdependensi) aktivitas ekonomi dan budaya. Sejumlah pihak berpendapat bahwa awal mula globalisasi terjadi di era modern (Hidayat 2017). Seiring dengan berjalannya waktu, berkembanglah taraf kehidupan manusia. Dari tidak mengenal tulisan hingga melahirkan pemikiran untuk membuat kodekode dengan angka dan huruf sehingga manusia dikatakan makhluk yang mampu berpikir atau sekarang disebut dengan kemampuan literasi.

Pengertian dari literasi itu sendiri ialah kemampuan berbahasa yang dimiliki oleh seseorang dalam berkomunikasi "membaca, berbicara, menyimak, dan menulis" dengan cara yang berbeda sesuai dengan tujuannya (Elizabeth Sulzby 1986). Jika didefinisikan secara singkat, definisi literasi yaitu kemampuan menulis dan membaca.

Menurut (Sigit Tri Utomo 2017), Masyarakat yang cerdas baik intelektual, sosial, emosional maupun spritual tentunya haruslah memiliki kemauan untuk membaca yang besar. Apalagi jika budaya membaca menjadi sebuah kebiasaan yang baik yang dilakukan masyarakat setiap hari, maka tentu jelas perpustakaan menjadi media dan bagian kehidupan yang secara tidak langsung menjadi kebutuhan primer yang harus dilakukan.

Perkembangan teknologi informasi di era millennial membuat masyarakat bisa mengakses informasi secara mudah dan cepat tanpa batasan waktu. Generasi yang terlahir di era millennial menganggap teknologi sebagai kebutuhan primer. Mereka tidak bisa lepas dari teknologi informasi dan komunikasi (Pratiwi and Asyarotin 2019). 
Saat ini konsep literasi terus berkembang dan terbagi dalam beberapa bentuk literasi, salah satunya adalah literasi digital. Gilster mendefinisikan literasi digital sebagai sebagai suatu kemampuan untuk memahami dan menggunakan informasi dari berbagai sumber digital. Tidak hanya mencakup kemampuan membaca, dibutuhkan proses berpikir secara kritis dan mengevaluasi informasi yang ditemukan melalui media digital.

Pentingnya literasi digital saat ini dirasakan juga oleh remaja terutama siswa sekolah. Menurut Undang-undang Pendidikan No. 2 Th. 1989 mengacu dari beberapa istilah murid, murid diartikan sebagai orang yang berada dalam taraf pendidikan yang dalam berbagai literatur murid juga disebut sebagai anak didik. Saat ini sistem pembelajaran tidak hanya berbatas antara guru dan murid. Dengan semua perkembangan teknologi kini siswa dapat mendapatkan informasi mengenai apapun termasuk pelajaran yang didapat dari sekolah melalui internet. Entah berupa jurnal, buku digital atau bahkan kursus yang dilakukan secara online tanpa perlu bertatap muka langsung dan terhalang oleh jarak dan waktu. Pendit (2009) dalam Husna (2019) mengatakan bahwa, "Era digital muncul ditandai dengan fenomena penggunaan internet oleh masyarakat dalam kehidupan sehari-hari. Ada dua kelompok masyarakat pengguna internet di era digital saat ini, yaitu generasi muda (digital native) dan generasi tua (digital immigrant)".

Berbicara mengenai kompetensi literasi digital, hal tersebut berguna untuk menghadapi informasi dari berbagai sumber digital yang terus berkembang seiring dengan berkembangnya teknologi informasi dan komunikasi sebagai dampak dari fenomena konvergensi media. Pengertian konvergensi media menurut (Preston 2001) adalah proses penggabungan berbagai media massa dan teknologi informasi ke dalam satu perangkat teknologi yang makin memudahkan pemiliknya untuk mengakses berbagai informasi dan tayangan. Jadi konvergensi lebih diartikan sebagai integrasi dari fungsi berbagai media ke dalam satu media baru yag lebih canggih. 
Pembelajaran masa kini dan lampau sangat berbeda dengan adanya perkembangan teknologi yang tidak pernah berhenti membuat inovasi. Sebut saja dengan metode belajar menggunakan laptop dan proyektor sebagai media pembelajaran. Lalu sumbersumber belajar yang bisa didapatkan dari internet. Begitu banyaknya hal yang di dapatkan dari perkembangan teknologi.

Penggunaan media digital di kalangan siswa hanya sebatas sebagai alat mencari sumber-sumber informasi yang terkait dengan bahan belajar. Lebih jauh lagi penggunaan internet dikalangan murid bisa juga untuk melakukan komunikasi dengan guru baik secara personal maupun melalui forum diskusi. Hal ini dilakukan sebagai upaya untuk menghadapi ledakan informasi yang tersedia di internet serta meningkatkan prestasi belajar siswa.

Prestasi belajar merupakan hasil belajar yang dicapai setelah melalui proses kegiatan belajar mengajar. Setiap kegiatan pembelajaran tentunya selalu mengharapkan akan menghasilkan pembelajaran yang maksimal.Untuk mendapatkan prestasi belajar yang baik bukanlah hal yang mudah, karena keberhasilan siswa dipengaruhi oleh beberapa faktor dan memerlukan usaha yang besar untuk meraihnya.

Begitu pula para siswa SMA Negeri 6 kota Bogor dimana penulis melakukan penelitian. Di era yang serba teknologi ini tidak menutup kemungkinan bahwa para siswa menggunakan internet sebagai sarana pembelajaran mereka. Sudah banyak prestasi yang telah diraih oleh SMA Negeri 6 seperti prestasi pada bidang desain grafis dan perfilman. Keadaan demografis sekolah yang berada di pusat kota Bogor membuat siswa terkena terpaan perkembangan teknologi.

Berdasarkan latar belakang diatas maka perumusan masalah yang muncul dalam penelitian ini yaitu "Bagaimana Hubungan antara Literasi Digital dengan Prestasi belajar siswa di SMA Negeri 6 Kota Bogor" 
Hipotesis penelitian yang akan diuji dalam penelitian ini adalah sebagai berikut:

1. $\mathrm{H}_{0}$ : Tidak terdapat hubungan antara kompetensi informasi dengan prestasi belajar siswa

$\mathrm{H}_{1}$ : Terdapat hubungan antara kompetensi informasi dengan prestasi belajar siswa

2. $\mathrm{H}_{0}$ : Tidak terdapat hubungan antara kompetensi komunikasi dengan prestasi belajar siswa

$\mathrm{H}_{1}$ : Terdapat hubungan antara kompetensi komunikasi dengan prestasi belajar siswa

3. $\mathrm{H}_{0}$ : Tidak terdapat hubungan antara kompetensi kreasi konten dengan prestasi belajar siswa

$\mathrm{H}_{1}$ : Terdapat hubungan antara kompetensi kreasi konten dengan prestasi belajar siswa

4. $\mathrm{H}_{0}$ : Tidak terdapat hubungan antara kompetensi keamanan dengan prestasi belajar siswa

$\mathrm{H}_{1}$ : Terdapat hubungan antara kompetensi keamanan dengan prestasi belajar siswa

\section{Kerangka Dasar Teori}

Marshall McLuhan untuk pertama kali mengenalkan Teori Determinasi pada tahun 1962 dalam tulisannya yang berjudul "The Guttenberg Galaxy: The Making of Typographic Man”. Pokok gagasan dari teori ini adalah bahwa perubahan yang terjadi dalam berbagai macam cara berkomunikasi akan membentuk pula keberadaan manusia itu sendiri. Teknologi membentuk individu bagaimana cara berpikir, berperilaku dalam masyarakat dan teknologi tersebut akhirnya mengarahkan manusia untuk bergerak dari satu abad teknologi ke abad teknologi yang lain (McLuhan, 1964).

Untuk mengukur tingkat literasi digital siswa, peneliti mengadopsi framework DIGCOMP yang dikembangkan oleh Europan Comission (Comission 2014) untuk mengetahui 
kompetensi digital siswa yang terdiri dari empat kompetensi dasar yaitu:

1) Kompetensi informasi, mencakup kompetensi siswa dalam mencari informasi melalui internet, menilai kebenaran informasi, dan penggunaan informasi tersebut secara bertanggung jawab.

2) Kompetensi komunikasi, mencakup kompetensi siswa untuk berpartisipasi dalam forum diskusi dan menggunakan berbagai fitur media sosial untuk berkomunikasi

3) Kompetensi kreasi konten, mencakup kompetensi siswa untuk menciptakan dan mengirimkan berbagai konten dan dokumen

4) Kompetensi keamanan, mencakup kompetensi siswa untuk menjaga keamanan data dan privasi melalui internet

Teori Konstruktivisme didefinisikan sebagai pembelajaran yang bersifat generatif, yaitu tindakan mencipta sesuatu makna dari apa yang dipelajari. Menurut teori ini, satu prinsip yang mendasar adalah guru tidak hanya memberikan pengetahuan kepada siswa, namun siswa juga harus berperan aktif membangun sendiri pengetahuan di dalam memorinya.

Dari uraian tersebut dapat dikatakan, bahwa makna belajar menurut konstruktivisme adalah aktivitas yang aktif, dimana peserta didik membina sendiri pengetahuannya, mencari arti dari apa yang mereka pelajari dan merupakan proses menyelesaikan konsep dan idea-idea baru dengan kerangka berfikir yang telah ada dan dimilikinya (Shymanski 1992).

Teori ini dapat dikaitkan dengan definisi prestasi belajar menurut Sia Tjundjing, prestasi belajar merupakan hasil kegiatan belajar, yaitu sejauh mana peserta didik menguasai bahan pelajaran yang diajarkan, yang diikuti oleh munculnya perasaan puas bahwa ia telah melakukan sesuatu dengan baik (Tjundjing 2001). Hal ini 
berarti prestasi belajar hanya bisa diketahui jika telah dilakukan penilaian terhadap hasil belajar siswa. Untuk prestasi belajar, penulis memilih rangking sebagai bentuk dari hasil kegiatan pembelajaran yang telah dilakukan oleh siswa.

\section{Metodologi Penelitian}

Jenis penelitian yang digunakan dalam penelitian ini adalah metode penelitian kuantitatif. Penelitian kuantitatif adalah suatu jenis penelitian yang pada dasarnya menggunakan pendekatan deduktif-induktif. Pengertian penelitian kuantitatif adalah suatu penelitian yang lebih banyak meggunakan logika hipotesis verifikasi yang dimulai denan berpikir deduktif untuk menurunkan hipotesis kemudian melakukan pengujian di lapangan dan kesimpulan atau hipotesis tersebut ditarik berdasarkan data empiris (Margono 2004).

Penelitian ini bertujuan untuk menguji apakah ada hubungan literasi digital dengan prestasi belajar siswa. penelitian ini diawali dengan mengkaji teori-teori dan pengetahuan yang sudah ada sehingga muncul sebab permasalahan. Permasalahan tersebut diuji untuk mengetahui penerimaan dan penolakannya berdasarkan data yang diperoleh dari lapangan. Adapun data yang diperoleh dari lapangan dalam bentuk skor tingkat kompetensi literasi digital dan prestasi belajar dalam bentuk angka-angka yang sifatnya kuantitatif.

Populasi dalam penelitian ini adalah siswa SMA Negeri 6 kota Bogor tahun 2018/2019. Hal ini dikarenakan siswa merupakan siswa aktif yang sedang menempuh pendidikan di sekolah dan termasuk dalam siswa yang tumbuh dalam perkembangan teknologi saat ini. Populasi pada penelitian ini berjumlah 666 siswa dimana siswa kelas X berjumlah 308 dan siswa kelas XI 358.

\section{Tabel 1}

Jumlah Siswa SMA Negeri 6 kota Bogor

Tahun 2018/2019

\begin{tabular}{ccc}
\hline No & Keterangan & Siswa \\
\hline 1 & Kelas $\mathrm{X}$ & 308 \\
\hline
\end{tabular}




\begin{tabular}{lll}
\hline 2 & Kelas XI & 358 \\
\hline & TOTAL & $\mathbf{6 6 6}$ \\
\hline
\end{tabular}

Sumber : Data administrasi SMA Negeri 6 Kota Bogor

Sampel pada penelitian ini adalah siswa SMA Negeri 6 kota Bogor. Menggunakan teknik penarikan sampel yaitu Probability Sampling yang merupakan suatu teknik pengambilan sampel yang memberikan kesempatan/ peluang yang sama untuk setiap anggota atau unsur populasi untuk dipilih menjadi anggota sampel (Sugiyono 2015). Dengan metode Stratified Sampling yang dimana populasi dalam sampling strata dibagi ke dalam sub-subpopulasi. Pertimbangan sampel penelitian ini ditujukan kepada siswa SMA Negeri 6 kota Bogor yang aktif tahun 2018-2019 yang pernah melakukan aktivitas pada penelusuran di internet.

Data yang penulis peroleh dalam penelitian ini dikumpulkan melalui angket, wawancara, observasi, dan studi kepustakaan. Teknik analisis data digunakan dalam penelitian ini adalah dengan data kuantitatif dengan menghitung sebuah nilai statistik. Skala pengukuran merupakan kesepakatan yang digunakan sebagai acuan untuk menentukan panjang pendeknya interval yang ada dalam alat ukur, sehingga alat ukur tersebut bila digunakan dalam pengukuran akan menghasilkan data kuantitatif (Sugiyono 2015). Teknik pengukuran dalam peneitian ini adalah menggunakan skala likert. Skala likert digunakan untk mengukur sikap, pendapat, dan persepsi seseorang atau sekelompok orang tentang fenomena sosial dalam penelitian, fenomena sosial ini telah ditetapkan secara spesifik oleh peneliti, yang selanjutnya disebut sebagai variabel penelitian (Sugiyono 2015).

\section{B. Pembahasan}

Penulis akan membahas dan memaparkan dari hasil penelitian yang telah dilakukan di SMA Negeri 6 kota Bogor. Adapun hasil dari uji validitas dan relibilitas menyatakan ke validan terhadap kuisioner yang disebarkan kepada responden. 
Penelitian ini dilaksanakan dengan menyebarkan angket kepada responden, dari 121 angket yang disebarkan dapat terisi semua oleh responden, yakni para siswa kelas X dan XI SMA Negeri 6 kota Bogor, sedangkan data yang diperoleh melalui wawancara, studi pustaka digunakan sebagai data dan informasi penunjang guna memperkuat dan memperdalam hasil penelitian yang diperoleh melalui angket.

Tabel 2

Hubungan Variabel/Sub Variabel Penelitian

\begin{tabular}{|c|c|c|c|c|}
\hline Korelasi & $\mathrm{r}$ & $\mathrm{t}_{\text {hitung }}$ & $\mathrm{t}_{\text {tabel }}$ & $\begin{array}{l}\text { Keeratan } \\
\text { Hubungan }\end{array}$ \\
\hline $\begin{array}{c}\text { X : Literasi Digital dengan Y : } \\
\text { Prestasi Belajar (Ranking) }\end{array}$ & 0,478 & 5,938 & \multirow{5}{*}{1,980} & Sedang \\
\hline $\begin{array}{c}\text { Kompetensi Informasi (X1) } \\
\text { dengan Y : Prestasi Belajar } \\
\text { (Ranking) }\end{array}$ & 0,218 & 2,433 & & Rendah \\
\hline $\begin{array}{c}\text { Kompetensi Komunikasi (X2) } \\
\text { dengan Y : Prestasi Belajar } \\
\text { (Ranking) }\end{array}$ & 0,259 & 2,922 & & Rendah \\
\hline $\begin{array}{c}\text { Kompetensi Kreasi Konten } \\
\text { (X3) dengan Y : Prestasi Belajar } \\
\text { (Ranking) }\end{array}$ & 0,487 & 6,079 & & Sedang \\
\hline $\begin{array}{c}\text { Kompetensi Keamanan (X4) } \\
\text { dengan Y : Prestasi Belajar } \\
\text { (Ranking) }\end{array}$ & 0,438 & 5,316 & & Sedang \\
\hline
\end{tabular}

Pada tabel di atas dapat dilihat koefisien korelasi Pearson (r) adalah sebesar 0,470 untuk variabel $\mathrm{X}$ literasi digital dengan variabel $\mathrm{Y}$, dengan hasil uji signifikansi diperoleh nilai t hitung 5,813 dan nilai $\mathrm{t}$ tabel 1,980 maka dapat dilihat bahwa $(5,813)>\mathrm{t}$ tabel $(1,980)$ sehingga Ho ditolak. Dengan demikian dapat diambil keputusan bahwa terdapat hubungan yang signifikan antara literasi digital (X) dengan prestasi belajar (Y) serta koefisien korelasi sebesar 0,470 menunjukkan keeratan hubungan antara variabel $\mathrm{X}$ dengan Y merupakan hubungan yang sedang.

Keterkaitan antara literasi digital dengan prestasi belajar ialah dilihat kompetensi informasi, kompetensi komunikasi, 
kompetensi kreasi konten, dan kompetensi keamanan (Comission 2014). Banyak manfaat literasi digital yang diberikan dalam mendukung prestasi belajar siswa. Manfaat-manfaat literasi digital seperti menghemat waktu, belajar lebih cepat, menghemat uang, membuat lebih aman, selalu memperoleh informasi terkini, selalu terhubung, membuat keputusan yang lebih baik, dapat membuat anda bekerja, membuat lebih bahagia, dan mempengaruhi dunia (Wright, 2015).

Untuk variabel X1 literasi digital dengan variabel Y, dengan hasil uji signifikansi diperoleh nilai t hitung 2,346 dan nilai $t$ tabel 1,980 maka dapat dilihat bahwa $(2,346)>\mathrm{t}$ tabel $(1,980)$ sehingga Ho ditolak. Dengan demikian dapat diambil keputusan bahwa terdapat hubungan yang signifikan antara literasi digital (X) dengan prestasi belajar (Y) serta koefisien korelasi sebesar 0,210 menunjukkan keeratan hubungan antara variabel $\mathrm{X}$ dengan $\mathrm{Y}$ merupakan hubungan yang rendah.

Keterkaitan antara kompetensi informasi dengan prestasi belajar ialah dilihat dari rangking, nilai, dan motivasi belajar siswa. kompetensi informasi yang baik akan membantu siswa dalam melakukan pencarian informasi dengan tepat. Hal ini juga membantu siswa dalam melaksanakan kegiatan belajar secara konstruktivisme dan mencapai hasil yang maksimal. Menurut Shymansky makna belajar konstruktivisme adalah aktivitas yang aktif, dimana peserta didik membina sendiri pengetahuannya, mencari arti dari apa yang mereka pelajari dan merupakan proses menyelesaikan konsep dan ide-ide baru dengan kerangka berfikir yang telah ada dan dimilikinya (Shymanski, 1992).

Untuk variabel X2 literasi digital dengan variabel Y, dengan hasil uji signifikansi diperoleh nilai t hitung 2,725 dan nilai $t$ tabel 1,980 maka dapat dilihat bahwa $(2,725)>\mathrm{t}$ tabel $(1,980)$ sehingga Ho ditolak. Dengan demikian dapat diambil keputusan bahwa terdapat hubungan yang signifikan antara literasi digital (X) dengan prestasi belajar (Y) serta koefisien korelasi sebesar 0,242 
menunjukkan keeratan hubungan antara variabel $\mathrm{X}$ dengan $\mathrm{Y}$ merupakan hubungan yang rendah.

Salah satu faktor rendahnya keeratan kedua variabel ini adalah jarangnya siswa berpartisipasi dalam forum diskusi yang memang tidak banyak. Meskipun begitu, terdapat keterkaitan antara kompetensi komunikasi dan prestasi belajar. Hal ini dapat dilihat dari rangking, nilai rata-rata kelas, dan motivasi belajar siswa. Pendapat dari Soewarno Handaya Ningrat (1980:94) Komunikasi adalah proses interaksi atau hubungan saling pengertian satu sama lain antara sesama manusia. Proses interaksi atau hubungan satu sama lain yang dikehendaki oleh seorang dengan maksud agar dapat diterima dan dimengerti antara sesamanya. Lahirnya new media, sebagai istilah generik yang digunakan untuk menggagas berbagai bentuk komunikasi interaktif berbasis media elektronik dengan memanfaatkan teknologi informasi, menjadikan proses komunikasi tidak lagi hanya melibatkan orang dengan orang, melainkan juga antara orang dengan media, orang dengan mesin, bahkan mesin dengan mesin, berproses secara interaktif dan sangat menakjubkan. Robot bicara, mesin bicara, buku bicara, adalah beberapa contoh yang menggambarkan perkembangan teknologi informasi dan komunikasi saat ini (Yusup and Saepudin 2017).

Untuk variabel X3 literasi digital dengan variabel Y, dengan hasil uji signifikansi diperoleh nilai t hitung 5,949 dan nilai $t$ tabel 1,980 maka dapat dilihat bahwa $(5,949)>t$ tabel $(1,980)$ sehingga Ho ditolak. Dengan demikian dapat diambil keputusan bahwa terdapat hubungan yang signifikan antara literasi digital (X) dengan prestasi belajar (Y) serta koefisien korelasi sebesar 0,479 menunjukkan keeratan hubungan antara variabel $\mathrm{X}$ dengan $\mathrm{Y}$ merupakan hubungan yang sedang.

Menurut KBBI konten adalah informasi yang dihadirkan melalui media atau produk elektornik. Berbagai cara untuk menyampaikan konten. Seperti menggunakan internet, televisi, surat kabar online, dan lain sebagainya. Konten yang disediakan pun harus menarik agar banyak yang melihat. Jenis-jenis konten paling 
diminati di internet menurut komunikasipraktis.com yang sudah berhasil dihimpun dari berbagai sumber adalah hiburan, liburan, video viral, meme, inspirasi, motivasi, dan masih banyak lagi. Keterkaitan kompetensi kreasi konten dengan prestasi belajar siswa bisa dilihat dari motivasi belajar mereka. Apakah konten tersebut sudah cukup menarik dan edukatif sehingga memotivasi mereka dalam belajar dan membuat mereka ikut dalam menciptakan dan mengirimkan berbagai konten dan dokumen yang berhubungan dengan pelajaran.

Untuk variabel X4 literasi digital dengan variabel Y, dengan hasil uji signifikansi diperoleh nilai t hitung 5,071 dan nilai $t$ tabel 1,980 maka dapat dilihat bahwa $(5,071)>t$ tabel $(1,980)$ sehingga Ho ditolak. Dengan demikian dapat diambil keputusan bahwa terdapat hubungan yang signifikan antara literasi digital (X) dengan prestasi belajar (Y) serta koefisien korelasi sebesar 0,422 menunjukkan keeratan hubungan antara variabel $\mathrm{X}$ dengan $\mathrm{Y}$ merupakan hubungan yang sedang.

Dalam kegiatan kompetensi keamanan, siswa mampu untuk menjaga keamanan data dan privasi melalui internet (Comission 2014). Keamanan sering kurang mendapat perhatian dari perancang dan pengelola sistem informasi. Masalah keamanan sering berada diurutan setelah tampilan, atau bahkan diurutan terakhir dalam daftar hal-hal yang dianggap penting (Wahana 2003).

Jika siswa menyadari betapa pentingnya menjaga keamanan data di internet, maka tidak perlu lagi mengkhawatirkan hal tersebut. Karena jika kita menyadari bahwa alangkah berbahayanya jika hal buruk terjadi pada data yang kita miliki. Sebut saja saat siswa menyimpan data berkaitan pelajaran di internet seperti google drive, jika suatu saat data itu hilang atau rusak karena kurangnya kepedulian terhadap menjaga keamanan maka akan berdampak pada rangking, nilai, bahkan motivasi belajar. 


\section{Simpulan}

Berdasarkan rumusan masalah yang peneliti ajukan dalam penelitian mengenai literasi digital dengan prestasi belajar siswa, maka dapat ditarik keismpulan.

Terdapat hubungan yang signifikan antara literasi digital dengan prestasi belajar siswa yang diukur dari kompetensi informasi, kompetensi komunikasi, kompetensi kreasi konten, kompetensi keamanan.

Terdapat hubungan yang signifikan antara kompetensi informasi dengan prestasi belajar siswa yang diukur dari kemampuan siswa dalam melakukan pencarian informasi di internet dan mampu mempertanggung jawabkan informasi yang telah ia telusuri dan gunakan untuk kegiatan belajar siswa dimana penggunaan internet dalam pencarian informasi ini memotivasi mereka dalam belajar.

Terdapat hubungan yang signifikan antara kompetensi komunikasi dengan prestasi belajar siswa yang diukur dari kemampuan siswa dalam melakukan diskusi mengenai pelajaran serta menggunakan media sosial sebagai sarana lain untuk menunjang kebutuhan mereka dalam belajar.

Terdapat hubungan yang signifikan antara kompetensi kreasi konten dengan prestasi belajar siswa yang diukur dari kemampuan siswa dalam melakukan pembuatan konten dan dokumen dimana itu dibutuhkan dalam proses pembelajaran mereka di sekolah. Karena hal tersebut bisa memberikan dampak pada rangking dan nilai mereka jika mereka memang menguasai hal tersebut.

Terdapat hubungan yang signifikan antara kompetensi keamanan dengan prestasi belajar siswa yang diukur dari kemampuan siswa dalam menjaga keamanan data serta privasi mereka di internet. Melihat seberapa pentingkah siswa menganggap bahwa menjaga keamanan data mereka terkait pelajaran. Karena bisa saja terjadi hal yang tidak diinginkan dimana itu dapat berpengaruh pada rangking, nilai, dan motivasi siswa dalam belajar 


\section{DAFTAR PUSTAKA}

Comission, Europan. 2014. "From Digital Competence Framework." 2014. http://www.ec.europa.eu.

Elizabeth Sulzby, William Teale. 1986. Emergent Literacy: Writing and Reading. Norwood: Ablex Publisihing Corporation.

Hidayat, Aat. 2017. "Rekonstruksi Peran Pustakawan Di Era Globalisasi." LIBRARIA: Jurnal Perpustakaan 4 (2): 467.

https://doi.org/10.21043/libraria.v4i2.1872.

Husna, Jazimatul. 2019. “Transformasi Kepemimpinan Bagi Pustakawan Di Era Digital A . Pendahuluan Transformasi Dan Perubahan Yang Semakin Cepat Di Era Digital Memberikan Dampak Bagi Pustakawan Dan Perpustakaan Dalam Mengambil Keputusan . Era Digital Muncul Ditandai Dengan Fenomen" 7 (1): 1-18.

Margono. 2004. Metodologi Penelitian Pendidikan. Jakarta: PT Rineka Cipta.

Pendit, Putu Laxman. 2009. Perpustakaan Digital: Kesinambungan \& Dinamika. Cita Karyakarsa Mandiri.

Pratiwi, Anggi, and Eflinnida Nurul Komaril Asyarotin. 2019. "Implementasi Literasi Budaya Dan Kewargaan Sebagai Solusi Disinformasi Pada Generasi Millennial Di Indonesia." Jurnal Kajian Informasi \& Perpustakaan 7 (1): 65-80. https://doi.org/10.24198/jkip.v7i1.20066.

Preston, Paschal. 2001. Reshaping Communications. London: Calif: Sage.

Shymanski, J. 1992. "Using Constructivist Ideas to Teach Science Teachers About Constructivist Ideas, or Teacher Are Students Tool." Journal of Science Teacher Education, 3 (2), 53-57.

Sigit Tri Utomo, Ahmad Sa’i. 2017. “Urgensi Eksistensi Perpustakaan Sebagai Upaya Pengurangan Perilaku Menyimpang Siswa Di Sekolah.” 
Sugiyono. 2015. R\&D, Metode Penelitian Kuantitatif Kualitatif Dan. Bandung: Alfabeta.

Tjundjing, Sia. 2001. "Hubungan Antara IQ, EQ, Dan QA Dengan Prestasi Studi Pada Siswa SMU." Jurnal Anima Vol.17 No.1.

Wahana. 2003. Konsep Jaringan Komputer Dan Pengembangan.No Title. Salemba Infotek.

Yusup, Pawit M., and Encang Saepudin. 2017. "Praktik Literasi Informasi Dalam Proses Pembelajaran Sepanjang Hayat." Jurnal Kajian Informasi \& Perpustakaan 5 (1): 79-94.

https://doi.org/10.24198/JKIP.V5I1.11387.G6030. 